Marquette University

e-Publications@Marquette

Theology Faculty Research and Publications

Theology, Department of

$3-1-2014$

Has the Silence Been Broken? Catholic Theological Ethics and Racial Justice

Bryan Massingale

Marquette University, bryan.massingale@marquette.edu

Published version. Theological Studies, Vol. 75, No. 1 (March 2014): 133-155. DOI. (C) 2014

Theological Studies, Inc. Used with permission. 


\section{Has the Silence Been Broken? Catholic Theological Ethics and Racial Justice}

\section{Bryan N. Massingale}

Marquette University

\section{Abstract}

This survey discusses the emerging contours of a distinctive Catholic ethical approach to race, racism, and racial justice. Among its features are the adoption of a more structural and cultural understanding of human sinfulness, engaged intellectual reflection, concern about malformed white identity, an intentional dialogue with African American scholarship and culture, and the cultivation of spiritual practices and disciplines. The "Note" concludes with a discussion of the global challenges of racialization and the future challenges for Catholic ethical reflection on racism.

\section{Keywords}

Catholic theological ethics; Catholic moral theology; race; racism; racial justice; racialization; whiteness; complicity; solidarity; spirituality; unconscious racisicm

$\mathrm{T}$

This "Note" surveys recent Catholic ethical and theological scholarship on the vexing issue of racism and the pursuit of racial justice. Two events set the context for this discussion. The first is the election of the first person of African descent to the office of President of the United States, Barack Obama, in 2008. Given this nation's preeminent role on the world stage, its troubled and tragic history of race relations, and its still unfinished task of ensuring equal justice and full acceptance for its residents of color, this election was a monumental event that both captured the 
attention of the world and became a new benchmark in the history of relations between the darker and lighter peoples of the world. ${ }^{1}$ In a typical expression of such sentiments, the International Herald Tribune declared that with Obama's election, America "leaped" across the color line and hailed the election of a "black man who made history both because of his race and in spite of it." ${ }^{2}$ My survey, then, focuses on Catholic scholarship published since that pivotal event.

The second contextualizing event is the second international gathering of Catholic theological ethicists in 2010 in Trento, Italy. A truly global assembly of more than 600 scholars met to consider the past, present, and future of the discipline. In a somewhat providential and unplanned confluence, this gathering both opened and concluded with plenary presentations that explored Catholic moral theology's engagement with the topic of racism. Looking at the discipline's past, Bryan Massingale described what he called the "systemic erasure of the black/dark-skinned body" and voice in the deliberations of Catholic moralists. Notwithstanding the fact that "race-based enslavement, conquest, and colonialism are common foundational experiences . . . that link the Americas, Africa, Europe, and Asia," he detailed how racial injustice and the perspective of its victims were never a major concern or significant preoccupation of Catholic theological ethics. Moreover, on the few occasions when previous generations of ethicists did address racism, Massingale noted how Catholic moral discourse "treated black people as objects of white study, analysis, and charity - and rarely as subjects capable of independent thought or creative analysis." The voice and agency of dark-skinned peoples "are muted, absent, erased - and at the same time opposed, feared, and resisted" in Catholic moral discourse of the past. In light of this sad legacy, Massingale challenged the assembly to understand that Catholic moral theology cannot

give an adequate account of present controversies and moral responsibilities-much less develop a Catholic theological ethics for a world church - if [it] fails to attend to the voices of the dark bodies that hover over and haunt our histories despite our embarrassed silence and studied neglect. ${ }^{3}$

The Trento assembly's final plenary session featured emerging scholars discussing the future of the discipline. In addition to presenters who detailed the critical importance of gender and cultural context for the future, María Teresa Davila noted that "with respect to the sin of racism, theological ethics has missed the mark." She urged the ethical guild to a deeper appreciation of the challenge of racialization and the

1. For a representative sampling of the global reaction to Barack Obama's 2008 election, see "Reactions from around the World," New York Times, November 5, 2008, http://thecaucus. blogs.nytimes.com/2008/11/05/reactions-from-around-the-world/? ${ }_{-}=0$. All URLs cited herein were accessed December 17, 2013.

2. As cited in "Barack Obama Is 'President of the World," CNN Politics.com (November 5, 2008), http://edition.cnn.com/2008/POLITICS/1 1/05/international.press.reaction.

3. Bryan Massingale, "The Systemic Erasure of the Black/Dark-Skinned Body in Catholic Ethics," in Catholic Theological Ethics Past, Present, and Future: The Trento Conference, ed. James F. Keenan (Maryknoll, NY: Orbis, 2011) 116-24. 
manifold ways that it both forms the epistemology of dominant social groups and marks many bodies as "other" in human societies. Thus, she declared that a "primary requirement" for the discipline's future "is for theologians and ethicists from a variety of historically racialized groups to come together and corporately take on the hard questions of privilege, institutional violence, racialization of the other, dehumanization of entire groups, and the essentialization of the white or European as paradigmatically human." 4

Thus in what was the most internationally representative gathering of Catholic theological ethicists in the discipline's history, ${ }^{5}$ concerns regarding race, racial justice, and racism emerged as both central omissions in Catholic moral theology's past and as essential challenges for its future. This survey, then, examines recent efforts of Catholic theologians and ethicists to answer the summons to a deeper engagement with the evil of racism. Happily, there is now a critical mass of recent literature to consider, and the contours of a distinctive Catholic approach to racial issues are coming into clearer focus. Yet, much remains to be done; this note concludes with an assessment of these recent efforts and the still unfinished tasks that await us if Catholic theological ethicists are to truly "break the silence" "with regard to this troubling social evil.

\section{Foundational Sources: Cone, Copeland, and Massingale}

Most of the recent literature treating Catholic theological ethics and race examined in this contribution acknowledges its indebtedness to and/or inspiration taken from the work of James H. Cone, M. Shawn Copeland, and Bryan N. Massingale. To properly understand the emerging Catholic approach to racism, then, it will be useful to begin with a survey of recent work by these scholars.

\section{James H. Cone: The Cross and the Lynching Tree ${ }^{7}$}

Including this work by an African American Protestant in a survey of recent Catholic moral theology requires explanation. Cone is the originator of and still a major figure in the field of Black Theology, the first form of liberationist theological reflection in North America. His works have significantly influenced the perspectives of leading Catholic theologians engaged in the study of race and racism, including Diana Hayes,

4. Maria Teresa Davila, "Racialization and Racism in Theological Ethics," in Catholic Theological Ethics 307-21.

5. So declares James Keenan, who recounts the painstaking detail and effort to ensure a truly comprehensive assembly representing the generational and global diversity of Catholic ethicists: "Introduction: The Trento Conference," in Catholic Theological Ethics 1-7.

6. The phrase comes from Laurie M. Cassidy and Alex Mikulich, eds., Interrupting White Privilege: Catholic Theologians Break the Silence (Maryknoll, NY: Orbis, 2007), a pathbreaking collection of texts that marks one of the first collaborative attempts by white Catholic theologians to engage white racial privilege as a central theological concern.

7. Maryknoll, NY: Orbis, 2011. 
Shawn Copeland, Jon Nilson, and Bryan Massingale. ${ }^{8}$ Moreover, throughout his career, Cone has shown a willingness to dialogue with and engage Catholic scholarship regarding racial justice that is unmatched by other black Protestant theologians. ${ }^{9}$ Finally, his understanding of the "cultural logic" behind the phenomenon of lynching is used by more recent scholars to understand the current reality of the hyper-incarceration of Black and Latino men in the United States. ${ }^{10}$

Cone's most recent monograph is a theological meditation on one of the most painful, horrifying, and tragic phenomena in the troubled history of US race relations: lynching - the brutally savage, extrajudicial, sadistic torture and public killings of African Americans, mostly men." As Cone notes, "In the 'lynching era,' between 1889 to 1940, white Christians lynched nearly five thousand black men and women ... in the name of God and in defense of segregation, white supremacy, and the purity of the Anglo-Saxon race."12 Describing it with uncharacteristic understatement as "a shameful and painful way to die," Cone details how such executions-which included shootings, hangings, and burnings often accompanied by excruciating dismembermentwere public spectacles and widely advertised events that occurred with the

8. Both Hayes and Massingale used Cone as a major source in their doctoral dissertations and have written major essays on him. See Diana L. Hayes, "James Cone's Hermeneutic of Language and Black Theology," Theological Studies 61 (2000) 609-31; and Bryan N. Massingale, "James Cone and Recent Catholic Episcopal Teaching on Racism," Theological Studies 61 (2000) 700-730. Jon Nilson acknowledges Cone's decisive influence in his "Confessions of a White Catholic Racist Theologian," Proceedings of the Catholic Theological Society of America 58 (2003) 64-82. An entire issue of this journal, guest edited by Shawn Copeland, was devoted to exploring the influence of Black Theology, particularly that of Cone, in Catholic theology (Theological Studies 61.4 [2000]). Moreover, Cone's importance for a younger generation of black Catholic scholarship is evidenced in Joseph Flipper and Katy Leamy, "Suffering as Glory in Hans Urs von Balthasar and James Cone," Journal of the Black Catholic Theological Symposium 7 (2013) 73-95.

9. For example, see Cone's essays: "A Theological Challenge to the American Catholic Church," in Speaking the Truth: Ecumenism, Liberation, and Black Theology (Grand Rapids, MI: Eerdmans, 1986) 50-60; "Black Liberation Theology and Black Catholics: A Critical Conversation," Theological Studies 61 (2000) 731-47; and "Theologians and White Supremacy: An Interview with James H. Cone," America (November 20, 2006), http://americamagazine.org/issue/592/article/theologians-and-white-supremacy.

10. See Alex Mikulich, Laurie Cassidy, and Margaret Pfeil, The Scandal of White Complicity in US Hyper-Incarceration: A Nonviolent Spirituality of White Resistance (New York: Palgrave Macmillan, 2013) 39-44 (treated in more detail below).

11. It should be noted that Cone's book is but one of several recent theological examinations of this disturbing practice. See Angela D. Sims, The Ethical Complications of Lynching: Ida B. Wells s Interrogation of American Terror (New York: Palgrave Macmillan, 2010); Anthony B. Pinn, The Terror and the Triumph: The Nature of Black Religion (Minneapolis: Fortress, 2009); and Kelly Brown Douglas, What's Faith Got to Do with It? Black Bodies/ Christian Souls (Maryknoll, NY: Orbis, 2005). See also, M. Shawn Copeland, Enfleshing Freedom: Body, Race, and Being (Minneapolis: Fortress, 2010) 117-12 (examined in more detail below). It remains true, however, that few scholars have probed the theological implications of lynching as thoroughly as Cone. One should note that, with the exception of Copeland, these authors are not Catholics.

12. Cone, Cross and the Lynching Tree 30-31. 
"widespread knowledge and explicit sanction" of government officials and the "tacit approval" of the churches. ${ }^{13}$ Noting that its use was intended to bolster a social order of white dominance and to silence any challenge to white control, our author describes lynching as "a ritual celebration of white supremacy" and as the ultimate expression of the callousness with which white society regarded the lives of African Americans and other persons of color. ${ }^{14}$

As horrific as this practice is, Cone probes its theological significance. This is twofold. First, Cone relates how this practice was both sanctioned by white Christianity and ignored by its leading theologians. He reports the speech given by a then-current US senator who proclaimed that lynching reflects "a divine right of the Caucasian race to dispose of the offending blackamoor without the benefit of a jury." Indeed, Cone concludes that the belief in the right to use any means to defend white supremacy "was grounded in the religious belief that America is a white nation called by God to bear witness to the superiority of "white over black." 15 Perhaps even more troubling to Cone, however, than the explicit religious legitimacy given to such racist barbarism is what he calls the "conspicuous absence" of the subject of lynching in US theological discourse. ${ }^{16}$

To illustrate this deafening and appalling silence, Cone offers an extended reflection on the career of Reinhold Niebuhr. Though "often called this nation's greatest theologian," and despite a manifest concern for many social evils of his time, Niebuhr never mentioned the scandal of race-based lynching that so afflicted the nation. Cone relates that such silence was all too typical of white Christian theologians "then and since" who "have typically ignored the problem of race, or written and spoken about it without urgency, not regarding it as critical for theology and ethics." He attributes Niebuhr's - and the white theological guild's - silence on lynching and avoidance of race to two factors: a lack of dialogue with "radical" black theological and social perspectives, and a disturbing absence of empathy for the plight of African Americans. ${ }^{17}$

The second theological significance Cone sees in the reality of lynching is its "analogy" with the cross of Jesus. Cone reads the horror of the crucifixion as a "first-century lynching." He describes both the cross and the lynching tree as "symbols of terror, instruments of torture and execution, reserved primarily for slaves, criminals, and insurrectionists - the lowest of the low in society." Both were public "spectacles," intended to "strike terror" and serve as warnings against defiance of social norms. ${ }^{18}$ However, Cone points out how such striking associations were better and more thoroughly developed by black artists, poets, and musicians than by white theologians.

13. Ibid. 5-9, 15.

14. Ibid. 9, 31. In another place, Cone aptly describes lynching as "state-endorsed terrorism" (23). It should also be noted that while he relates that there are 5,000 victims of this shameful practice, most authorities agree that these are but the known or acknowledged victims, and that the true number is most likely much higher. Two valuable studies are Philip Dray, At the Hands of Persons Unknown: The Lynching of Black America (New York: Random House, 2002); and W. James Allen, Without Sanctuary: Lynching Photography in America (Santa Fe, NM: Twin Palms, 2000).

15. Cone, Cross and the Lynching Tree 7.

16. Ibid. 30 .

17. Ibid. $53-60$.

18. Ibid. 31 . 
Where theologians adopted a stance of tacit approval or dispassionate disinterest, African American poets such as Countee Cullen declared that "the South is crucifying Christ again." 19 The black arts, then, developed a theology showing how in the United States "the clearest image of the crucified Christ was the figure of an innocent black victim, dangling from a lynching tree." 20 This, then, becomes the reason why Cone writes this monograph. He seeks to establish the fact that both the cross and the lynching tree need each other. He concludes that the cross needs the lynching tree "to remind Americans of the reality of suffering - to keep the cross from being a symbol of abstract, sentimental piety." And without the cross, the lynching tree "becomes simply an abomination" devoid of hope. ${ }^{21}$ The cross, then, enables Christians to stand in solidarity with the victims of unjust suffering and grounds more authentic racial justice praxis.

Given Cone's indisputable influence on the shape of theological reflection on race both in the United States and abroad, this survey could not but take notice of this significant contribution. His profound meditation on such a searing and troubling episode establishes a number of themes that will continually appear in the Catholic literature surveyed: the shocking theological silence that attends the treatment of racism; the lack of empathy of the privileged toward the plight of those racially marked as "other"; the "cultural logic" that continues to ground social callousness toward persons of color; and the existence of resources within the Christian faith tradition that can foster genuine cross-racial solidarity and a more effective justice praxis.

\section{Shawn Copeland: Enfleshing Freedom: Body, Race, and Being ${ }^{22}$}

Shawn Copeland's theological career is marked by a constant interrogation and interruption of socially dehumanizing practices such as racism. ${ }^{23}$ In this monograph, Copeland deepens her engagement with this social reality by placing the body-and specifically the black body and the black woman's body -at the center of theological discourse and ethical inquiry. This rich meditation on race and embodiment begins by detailing how the black body, being a "structural embarrassment" in Western culture, has been excluded from the "beautiful." Using the Lonerganian categories of bias,

19. From Countee Cullen's poem, "Christ Recrucified," cited in full in Cone, Cross and the Lynching Tree 93.

20. Ibid.

21. Ibid. 161 .

22. Minneapolis: Fortress, 2010.

23. A full listing of Copeland's work on this subject is prohibitive. I mention only these very influential essays: "Racism and the Christian Vocation of the Theologian," Spiritus 2 (2002) 15-29; and "Political Theology as Interruptive," Proceedings of the Catholic Theological Society of America 59 (2004) 71-82. See also more recent essays, "The (Black) Jesus of Detroit: Reflections on Black Power and the (White) American Christ," in Christology and Whiteness: What Would Jesus Do?, ed. George Yancy (New York: Routledge, 2012) 18095; and "The Critical Aesthetics of Race," in She Who Imagines: Feminist Theological Aesthetics, ed. Laurie Cassidy and Maureen H. O'Connell (Collegeville, MN: Liturgical, 2012) 73-85. 
horizon, and scotosis, Copeland examines how "skewed racial visibility" keeps members of the dominant race from truly seeing black bodies. Instead, these bodies become "overdetermined," that is, identified as "crime, wanton, sexuality, evil, and sin."24 Thus, if beauty connotes the sacred, salvific, and intelligible, in the horizon of racism the black body "cannot be beautiful . . [but rather] repulsive, hideous; it encodes the demonic, the disposable, the lost, and the vacant." ${ }^{25}$ Such a bias-induced horizon, with its derogatory understanding of black embodiment, cannot but result in the gravest social injustices being perpetrated with impunity on persons of color in Western societies. ${ }^{26}$

Though specifically a work of theological anthropology, this monograph has great significance for theological ethics. First, Copeland advances a "new anthropological subject" for Christian theological and ethical concern: exploited, despised. poor women of color. ${ }^{27}$ She asks what may be considered a programmatic question: "What might it mean for poor women of color to grasp themselves as human subjects, to grapple with the question of liberation and freedom?"28 This question, which demands a radical reorientation of the focus of ethical concern, has far-reaching, even revolutionary, consequences for Catholic moral theology. For example, given moral theology's past predilection for seeing black bodies as objects of study, analysis, and reflection, and seldom as self-determining moral subjects with ethical agency, Copeland's demand for recognizing poor women of color as subjects entails honoring their experience, their cultural artifacts, and their intellectual productions as valid sources for ethical knowledge and reflection. It means that the poor and despised, especially those doubly burdened by race and gender, can do theological ethics. In short, they have the ability to think! And thus, they also have the ability to challenge the unnamed white/European and male hegemony that has characterized Catholic moral reflection for so long.

Second, Copeland's work insists that Catholic theological ethics take seriously the profound nexus between race and gender. For her, race and gender are "co-constitutive." Human bodies are simultaneously "raced" and "gendered." Thus, race and gender do not function as stand-alone categories. They mutually and reciprocally influence the fates of social groups:

Red, brown, yellow, poorwhite, and black female bodies-violated and "occupied" in empire-building, poached in the process of globalization-function as exotic and standard commodities for trafficking and sex tourism, pomographic fantasy, and sadomasochistic spectacle. Red, brown, yellow, and, especially, black male bodies lynched and castrated in

24. Copeland, Enfleshing Freedom 12-17.

25. Ibid. 18.

26. Throughout her monograph, Copeland notes how the bias of antiblack racism is not unique to the United States (ibid. 136). Citing the insight that "globalization is a re-racialization of the world," she notes that international neoliberal capitalism both preys on and consumes the bodies, labor, and sexuality of "yellow, brown, poorwhite, and black children, women, and men" (ibid. 66).

27. Ibid. 89 .

28. Ibid. 88 . 
empire-building, mechanized in the process of globalization, now are caricatured as "sexually aggressive, violent, animalistic." ${ }^{29}$

Acknowledging the co-constitutive nature of race and gender opens fruitful avenues for future exploration in Catholic moral theology, but it also carries significant challenges. It would entail a major rethinking of Catholic sexual ethics, moving this discourse beyond a preoccupation with forbidden sexual acts or the requirements of just, loving relationships to a consideration of how sex-based violence functions as a means of social subjugation and racial dominance.$^{30}$ It would also immensely complicate Catholic theological ethics' incipient engagement with the category of gender by requiring one to see that gender never arrives unaccompanied by race and class. ${ }^{31}$ Moreover, Copeland's project reframes the discussion of same-sex ethics as well, casting that discourse not only in terms of the morality of such sexual acts but also as an interrogation of "the heterosexual service of white male privilege." Indeed, Copeland poses the haunting question, Can Jesus of Nazareth be an option for gays and lesbians? She forthrightly responds, "If Jesus of Nazareth, the Christ of God, cannot be an option for gays and lesbians, then he cannot be an option." 32 Copeland recognizes that this question demands a serious reconsideration of Christology; it also has profound implications for Catholic moral theology and Christian discipleship.

Finally, Copeland's work treats the virtue of solidarity in light of the ethical implications of eucharistic anamnesis. Given the highly conflictual social order that treats the bodies of poor women of color with disdain, Copeland views the summons to solidarity, that is, a stance of "intelligent, active, compassionate love for the other" in the midst of social division and injustice, to be a task of the highest ethical priority. ${ }^{33}$ But this stance is not simply an intellectual one; authentic solidarity is performative and leads to effective and courageous praxis. She grounds this understanding in the eucharistic action of the faith community. For her, solidarity stems from anamnesis, an intentional "re-membering" of history's victims. And this memory achieves its most privileged expression in eucharistic worship, which "forms our social imagination, transvalues our values, and transforms the meaning of our being human," especially by investing exploited and despised black bodies with eschatological meaning. ${ }^{34}$ Such

29. Ibid. 73. On the nexus between racialization and gender-based violence from a Latino/a perspective, see Nancy Pineda-Madrid, Suffering and Salvation in Ciudad Juarez (Minneapolis: Fortress, 2011).

30. One of Massingale's current projects is a monograph that explores Catholic complicity in racialized sexuality and sexual racism that seeks to offer more effective responses to such social harms.

31. UK ethicist Julie Clague's Trento plenary paper, "Gender and Moral Theology: A Shared Project," in Catholic Theological Ethics 282-95, provides a recent summons to Catholic moralists to more adequately engage the reality and challenge of gender. Gender is indeed a major concern for the future of theological ethics, but Copeland would insist that the discipline also realize that race and gender are not stand-alone categories. Thus a dual or compounded impoverishment and challenge looms over Catholic moral theology now and into the foreseeable future.

32. Copeland, Enfleshing Freedom 77-78, emphasis original.

33. Ibid. 94.

34. Ibid. 125-27. 
solidarity both demands and sustains forms of social discipleship that are both uneasy with racial and gendered forms of marginalization and active in the struggle to overturn them. Implicit in Copeland's reflections, then, is a call for Catholic theological ethics not only to attend to the sacramental sources of Christian discipleship but also to more deeply appreciate their inherent social consequences in a world rent by racial supremacy and gendered domination. ${ }^{35}$

\section{Bryan N. Massingale: Racial Justice and the Catholic Church ${ }^{36}$}

Massingale's contributions to Catholic moral theology have been shaped by the overarching question, What would Catholic moral theology look like if it took the black experience seriously as a dialogue partner? ${ }^{37}$ This monograph, greeted as a major contribution and the subject of several review symposia, ${ }^{38}$ is a systematic examination of both the limits and contributions of Catholic theological ethics to the struggle against racial injustice. Three pivotal ideas, reflected in recent Catholic literature, will be presented: a cultural understanding of racism; a reframing of the task of racial reconciliation; and the role of lament (and the importance of the nonrational in Catholic ethical reflection) in achieving racial justice.

Massingale takes issue with the almost exclusive focus on an individual's acts of deliberate, intentional, and conscious race-based wrongdoing that dominate both popular discourse and official Catholic teaching. Drawing on Lonergan's insights that culture is a set of meanings and values that forms a people's way of life, and that this value set stands to society as the soul to the body, Massingale posits that racism, at its deepest level, is a culture that shapes group and personal identity. Racism is a deep set of formative meanings and values attached to skin color that decisively affects group identity and social consciousness, so much so that race often operates as a nonconscious factor in human decision-making, influencing behavior and beliefs without an individual's conscious awareness (i.e., "unconscious racism"). While this cultural formation affects all, it has a particular influence on white Americans (and white Europeans, though perhaps in different ways). They become socialized, in unconscious and preconscious ways, to their proper "place" in Western culture and American society. White Americans take on a "white" identity, a "white" way of being. They come to see their white selves, bodies, and values as "normal," "American," and/or

35. Laurie Cassidy echoes Copeland's call for anamnesis in her ethical reflection on the hyper-incarceration of Black and Latino men. See her "White Christian Amnesia and Anamnesis," in Scandal of White Complicity 105-8.

36. Maryknoll, NY: Orbis, 2010.

37. Massingale states the import of this question in his "Vox Victimarum. Vox Dei: Malcolm X as a Neglected 'Classic' for Catholic Theological Reflection," Proceedings of the Catholic Theological Society of America 65 (2010) 63-88.

38. "Review Symposium," Horizons 37 (2010) 127-42; "Review Symposium," U.S. Catholic Historian 29.2 (Spring 2011) 61-68; and "Bryan N. Massingale's Racial Justice and the Catholic Church," in Ecclesiology and Exclusion: Boundaries of Being and Belonging in Postmodern Times, ed. Dennis M. Doyle, Timothy J. Furry, and Pascal D. Bazzell (Maryknoll, NY: Orbis, 2012) 119-35. 
"Catholic" in a taken-for-granted way. This reality is conveyed in one of the most cited passages of this text:

What makes the US Catholic Church a "white racist institution," then, is not the fact that the majority of its members are of European descent (especially since in many places, they no longer are), nor the fact that many of its members engage in acts of malice or bigotry. What makes it "white" and "racist" is the pervasive belief that European aesthetics, music, theology, and persons-and only these-are standard, normative, universal, and truly "Catholic." 39

Thus Massingale argues that Catholic theological ethics must attend to the nonrational aspects of racism, that is, to those deeply ingrained and often preconscious patterns of meaning and value that undergird both personal behavior and institutionalized systems of racial advantage, privilege, and benefit. ${ }^{40}$

This more systemic and cultural understanding of racism reframes the task and goal of racial reconciliation in justice praxis. Reconciliation is neither a matter of establishing friendly and inclusive relationships between individuals, nor does it entail only personal repentance from past acts of racial animus. Rather, racial reconciliation requires challenging and severing the cultural nexus between skin color and racebased systemic advantage and privilege. It means challenging the propensity to condemn interpersonal racial injustices while defending white structural advantage and social dominance. Racial reconciliation, if its goal is the establishment of just relationship between unequal social groups, demands the elimination of the stigma and privilege associated with race.

While Massingale advances several strategies for structural and systemic change that would promote this end, "lament" emerges as most critical. Because racism forms people in visceral and nonconscious ways, there are limits to the effectiveness of intellectual analysis, rational appeals, and discursive practices in combating it. He argues that Catholic theological ethics must attend in more intentional ways to the power of the nonrational in its ethical reflection. He is convinced that "we act justly not because we are intellectually convinced, but because we are passionately moved." ${ }^{41}$ Inspired by the biblical text and African American cultural artifacts such as poetry and the spirituals, Massingale advances lament-expressions of pain, rage, sorrow, grief, and paradoxical hope-as a practice that has the power to pierce the social callousness and blindness of the racially advantaged toward the pain of persons of color. It provides the visceral motivation and spiritual strength for both the privileged and the stigmatized to engage in risky practices of boundary-crossing and cross-racial solidarity that can become the basis for more effective racial justice praxis. ${ }^{42}$

39. Massingale, Racial Justice 80 .

40. Ibid. 125-26.

41. Ibid. 116 .

42. Ibid. 104-16. But see Agbonkhianmeghe E. Orobator's cautions about the limits of lament as a strategy for justice, particularly his poignant observation that black peoples have been lamenting, but often to no effect: "If lament has not changed the status quo in so many 
Thus, Massingale's work advances an agenda for Catholic moral theology's future engagement with and reflection on racial justice. Such an agenda would include a deeper understanding of social sin in light of cultural (mal)formation; a renewed understanding of both conscience and the challenge of conscience formation, given the reality of unconscious racial motivation and bias; the ethical implications of belonging to a compromised or idolatrous faith; and further work on the spirituality needed for authentic lament and effective cross-racial solidarity in the midst of social conflict.

\section{Major Characteristics of Recent Catholic Reflection on Racial Justice}

In light of this in-depth consideration of these foundational figures and their recent texts, we now consider the signal themes and approaches present in other recent work that I believe constitute the emerging contours of a Catholic ethical approach to the issues of race, racism, and racial justice.

\section{Engaged Intellectual Reflection}

One very striking characteristic of Catholic racial analysis and ethical inquiry is a marked preference for concrete reasoning over abstract speculation. In other words, Catholic race discourse is a form of intellectual reflection in which involvement with pressing social issues serves as the springboard for ethical insight and analysis. Most of the scholars considered here discuss, develop, and clarify moral principles and concepts in light of their committed engagement with the injustice they strive to challenge ${ }^{43}$ The concrete struggles of those affected by racial injustice-who are of all races, though they are affected in different ways - often are the catalysts for the cultural analysis that informs ethical discernment. While not at all forsaking intellectual precision, recent Catholic ethical discourse on race is less interested in methodological discussion and refinement as ends, but rather for the sake of engaged social praxis. Indeed, as I will show, there is a questioning of the utility and adequacy of an overreliance on discursive analysis for confronting social evil. In a word, Catholic racial reflection tends to be liberationist both in method and intent, even if all the participants in this discourse would not necessarily consider themselves liberation theologians. A few examples will clarify the import of such engaged participatory reflection.

centuries, what guarantee is there that it would in our day and age?" (Orobator, "The Struggle against Racism and the Global Horizon of Christian Hope," in Ecclesiology and Exclusion 125-29, at 127).

43. This approach is in contrast to that found in recent works sometimes called the "new Black Theology." These works evidence a more abstract and dispassionate discourse as compared with previous work in Black Theology. While containing brilliant theological analysis and insight, they are less socially engaged and immediately relevant to the struggle against racism than their predecessors. Two exemplary examples of this approach in Protestant Black Theology are J. Kameron Carter, Race: A Theological Account (New York: Oxford University, 2008); and Willie James Jennings, The Christian Imagination: Theology and the Origins of Race (New Haven, CT: Yale University, 2010). 
Hyper-Incarceration: Complicity vs. Cooperation. The scandal of the vastly disproportionate imprisonment of Black and Latino men in the United States moves Alex Mikulich, Laurie Cassidy, and Margaret Pfeil to develop an in-depth analysis of the underlying "cultural logic" of white supremacy that continues to infect US life despite official policies of racial equality. They use the term "hyper-incarceration" to underscore their central ethical concern, which is not only that the United States imprisons far more people than any other nation (so-called "mass incarceration"), but also the more disturbing issues of who are being imprisoned and who they are. ${ }^{44}$ The incarcerated are not representative of the demographics of US society. The fact that this nation imprisons a higher percentage of persons of color than did South Africa at the height of apartheid is but one indicator that the authors take as "the latest reincarnation of the relationship between white domination and the subordination of people of color in the U.S." that "has never been fundamentally dismantled."45

A key methodological move made in this text that is of particular relevance for a Catholic theology of racial justice is the shift from cooperation to complicity. The authors question the casuistry of the moral manuals on cooperation with evil and its adequacy for understanding contemporary forms of social wrongdoing. Our authors assert that traditional Catholic moral theology's approach to cooperation presumes the innocence of the moral agent by locating the evil of a social situation at a degree of distance or remove from him or her. Cooperation also assumes a degree of deliberate intent and conscious agency. However, such assumptions are problematic for understanding and confronting the reality of white racial privilege and whiteness as an unquestioned social perspective; its major failing is that "the language of cooperation does not get at the moral conundrum of being white" in a culture of white privilege.

Thus, Mikulich, Cassidy, and Pfeil advocate for the primacy of "complicity" as a tool of ethical analysis. "Complicity" refers to "the ways that whites benefit from, consciously and unconsciously participate in, and contribute to the policies, laws, institutions, and social structures that create, sustain, and perpetuate hyper-incarceration" and white social dominance. ${ }^{46}$ Complicity better captures the (at times) involuntary and inadvertent entanglement with oppression and sinful social structures that arises from a more cultural understanding of racism.

Needless to say, the centrality of complicity advocated by these ethicists will have far-reaching implications for moral reflection and praxis that have yet to be fully appreciated. Thus we see how concrete engagement with the evil of racism, here understood as the continuation of white racial supremacy as evidenced in the massively disproportionate imprisonment of men of color, leads to significant development in Catholic ethical concepts.

Community Murals and the Aesthetics of Race. Maureen O'Connell provides an elegant, evocative, and compelling reflection on racial division, reconciliation, and analysis

44. Scandal of White Complicity 12,35 .

45. Ibid. 32-33.

46. Mikulich, Cassidy, and Pfeil, Scandal of White Complicity 8-9, 33. 
through excavating the theological significance of community muralism in the city of Philadelphia. ${ }^{47}$ Muralism describes the practice of painting images, commissioned and developed by the residents of a neighborhood, on the facades of buildings that reflects their trials, struggles, tragedies, dreams, and hopes. By examining these often dramatic and deeply moving works and, just as important, the detailed consultative process of their creation, O'Connell seeks to explore and develop the "largely unexplored" relationship between theological aesthetics and ethics.

My survey cannot convey the richness of O'Connell's work. I highlight but one key consideration for a Catholic theology of racial justice. O'Connell uses aesthetics as a way of highlighting "the affective dimensions of urban poverty" and race; she underscores the often overlooked yet critical role of the emotions and imagination in ethics. If racism affects us viscerally and nonrationally, as Massingale and others who adopt a more cultural understanding of racism believe, then analytical ethical discourse and appeals to the intellect are of limited utility. Beauty, O'Connell submits, has the power to address the nonrational barriers to human unity that contribute to the current impasse in US race relations. Building on recent scholarship on the virtue of solidarity in Catholic social thought, O'Connell embraces an "aesthetic solidarity." By this, she means

a persevering commitment to become more fully human by risking the vulnerability that comes either with creative self-expression or with de-centering of the self that accompanies engagements with such expressions so that we might tactilely experience together in our bodies and hearts what it feels like when we are "all really responsible for all." Aesthetic solidarity is a series of generative practices through which people of different religious traditions and economic enclaves learn how to imagine together, to create together, and to build together the kind of communities, city, [and] nation in which they want to live.48

The "inductive reasoning, intuition, kinesthetic thinking, and fantasy" connoted by aesthetic solidarity have the potential to more productively engage the affective dimensions of social injustice and break people out of "narrow, binary, hierarchical, and increasing[ly] polarizing ways of understanding themselves, others, or social circumstances." 49 I do not read $\mathrm{O}^{\prime}$ Connell as disparaging the need for public policy initiatives that redress entrenched race-based poverty, incarceration, and urban violence. Rather, her engagement with the art of those most impacted by such realities reveals the limits of prevailing Catholic ethical discourse and provides a catalyst for developing both new approaches in the struggle against racism and deeper understanding of some of moral theology's central social principles.

47. Maureen H. O'Connell, If These Walls Could Talk: Community Muralism and the Beauty of Justice (Collegeville, MN: Liturgical, 2012).

48. Ibid. 259.

49. Ibid. 260 . 
Trapvon Martin and an "Examination of Culture". A final example of how concrete engagement both typifies recent literature and leads to new ethical insight stems from the controversy in the United States over the shooting of an innocent unarmed black male teenager by a rogue private individual who stalked and pursued him against the explicit orders of the local police. This child's death and the subsequent acquittal of the teen's killer sparked outrage from the African American community, but curiously little public comment from Catholic officials.

Ethicists Bryan Massingale and Maureen O'Connell were among the few Catholic voices present in the public discussion. Both use the occasion of the Martin tragedy to probe the limits of Catholic engagement with race and the need to attend to racism's nonrational dimensions. Massingale employs the art form of the "blues"- "a feeling of frustration and sorrow in the face of harsh reality; a refusal to surrender despite deep pain"- to highlight the visceral anger of black men, as well as the deep fear of and lack of empathy toward them on the part of many white Americans that allow racial profiling to be accepted as a reasonable public practice. O'Connell notes how a shallow understanding of racism feeds both white denials over its existence and an insistence on individual rectitude in the face of its manifestations. Such white innocence poisons social discourse and stymies effective response. Both authors use concrete engagement with a pressing social issue to argue for a deeper understanding and further development of key ethical concepts such as solidarity (understood as the need to see the other as a human being) and the need to move from "an examination of conscience to an examination of culture." 50

\section{Interrogation of the White "Habitus" or Sense of Self}

Stemming from an appreciation of racism as a culture of white identity formation, another signal feature of recent Catholic literature is a deep concern with the white sense of self. This cannot but be a major concern in Catholic race analysis, given the dominance of white Americans and Europeans in the Catholic Church. Put another way, many of the Catholic theologians and ethicists in this survey-being socially identified as white and realizing that whiteness (as a stance of unremarked privilege, perspective, and evaluation) is at the core of racism-strive to examine "the moral

50. Maureen H. O'Connell, "Catholics and Racism: From Examination of Conscience to Examination of Culture," National Catholic Reporter, March 30, 2012, http://ncronline. $\mathrm{org} /$ news/peace-justice/catholics-and-racism-examination-conscience-examination-culture; and Bryan N. Massingale, "When Profiling Is 'Reasonable,' Injustice Becomes Excusable," NCR, July 19, 2013, http://www.uscatholic.org/blog/201307. For two other examples of how engaged reflection on current controversies can lead to refinement in understanding social ethical concepts, see Bryan N. Massingale, "The Scandal of Poverty: 'Cultured Indifference' and the Option for the Poor Post-Katrina," Journal of Religion and Society, supplement 4 (2008) 55-72; and Shawnee Daniels-Sykes, "Still We Remain: Living Religious Liberty Consciously and Unconsciously," Journal of the Black Catholic Theological Symposium 6 (2012) 77-99. 
conundrum of being white" and make sense of their white Christian identity in a culture of white privilege. ${ }^{51}$

Mikulich, Cassidy, and Pfeil frame this discussion around the notion of "white habitus," that is, a "racialized, uninterrupted socialization process that conditions and creates whites' tastes, perceptions, feelings, and emotions, and their views on racial matters," that facilitates white internalization of both white superiority and black inferiority. ${ }^{52}$ Incubated through ordinary, everyday practices, this habitus or perspective on reality engenders a form of "false consciousness" whereby pervasive cultural malformation leads white Americans to regard "morally disordered," race-based disparities in power, wealth, and social capital as "normatively right." 53 This helps explain the difficulty white Americans have in taking responsibility for their unacknowledged fears, biases, and attitudes - or even in making sense of the concept of "white complicity." This habitus creates a barely conscious form of dissonance that inhibits moral responsibility and awareness: "I may be consciously committed to all people being equal, and to universal principles of justice and fairness, but encountering a black man I may have feelings in my body of aversion, fear, avoidance and discomfort" that are difficult to admit or explore. ${ }^{54}$

From a similar point of view, O'Connell probes the "code of whiteness," a set of cultural norms and expectations that shapes white behavior and beliefs, much as the "code of the streets" influences life in urban America, though subjected to far less public scrutiny. Indeed, it is this lack of public acknowledgment that constitutes this code's most defining feature: "At the heart of whiteness is a willful ignorance about the impact of one's social location on one's perceptions or the inability to identify sufficiently the values and practices of whiteness at the heart of the various '-isms' that sustain violent social inequity." $O$ 'Connell specifies these values as confidence in the moral goodness of whites; a belief that social inequity is the result of market forces or individual choice; the privileging of rationalism and deductive reasoning over emotion and intuition; and the primacy of "autonomous individualism." Thus the code's core insistence of white racial innocence becomes a major obstacle to authentic racial solidarity and effective action against unjust racial advantage. ${ }^{55}$

Karen Teel also weighs in as a white scholar pondering the moral and existential quagmires of white racial identity. Reflecting on the question, Would Jesus be white?, she observes that for most white Christians, "the idea that whiteness is so destructive that Jesus could not risk white skin today is . . sobering"; it makes many uneasy. Yet cultivating a nagging discomfort with the inherent unjust privileging of one's white

51. Mikulich, Cassidy, and Pfeil, Scandal of White Complicity 9.

52. Ibid. 76. They borrow the term "white habitus" from Puerto Rican sociologist Eduardo Bonilla-Silva, Racism without Racists: Color-Blind Racism and the Persistence of Racial Inequality in the United States, 2nd ed. (Lanham, MD: Rowman \& Littlefield, 2006) 103.

53. Mikulich, Cassidy, and Pfeil, Scandal of White Complicity 145.

54. Ibid. 95.

55. O'Connell, "Code of Whiteness," If These Walls Could Talk 101-10. 
skin - so much so that one painfully accepts that "Jesus would not or could not be white today"-is precisely the precursor to the conversion needed for proactive racial justice and solidarity. For Teel, such a conversion would not entail giving up one's white skin, but "belonging to one's social group in a new way," namely, in a way that never stops asking critical questions about the absence or token presence of darkskinned bodies in places of social, cultural, and political power-and this absence's often death-dealing consequences. ${ }^{56}$

From a slightly different perspective comes Christopher Pramuk. While not disagreeing with the essential thrust of the above authors over the challenges of white racial innocence, he is sensitive to how the language of white privilege is heardnamely, defensively — by most white people: "You are white. Therefore you benefit from white privilege. Therefore you are the problem." Such defensiveness facilitates neither the needed personal conversion nor the social transformation desired. Pramuk advocates what he calls "graced encounters," that is, disturbing yet consoling crossracial experiences and events that draw one-perhaps unwittingly and unexpectedlyinto new relationships with one's self and others. ${ }^{57} \mathrm{I}$ do not read Pramuk as being in radical disagreement with Mikulich, Cassidy, Pfeil, O'Connell, and Teel; rather, he seeks to create the existential space within white people so that the "moral conundrums of whiteness" advanced by the others can be more fruitfully heard.

\section{Spirituality as a Crucial Resource for Racial Justice}

These disturbing assessments of skewed and deformed white racial identity lead the authors surveyed to develop in-depth reflections on spirituality, conversion, and spiritual practices such as contemplative prayer as essential and vital resources for dispelling false consciousness and achieving racial justice. This feature looms large in recent Catholic literature on race. For example, Cassidy bluntly tells white people, when afflicted with a deep sense of unease with their compromised racial identity, to dwell in this uneasiness. The urge to "do something," to come up with an action plan, only feeds the problematic need for white people to be in control. She declares that fostering a contemplative "willingness to be with the radical contradiction of our white everyday existence - in its pain, confusion, powerlessness, and vulnerability - that is 'doing something."'58 Similarly, Pramuk counsels against a rush to social action and political engagement in response to an acute awareness of how racism harms people of all racial groups. Premature social engagement, he warns, neglects the essential "source of all loving action," which he calls "the contemplative mirror." By this he

56. Karen Teel, "What Jesus Wouldn't Do: A White Theologian Engages Whiteness," in Christology and Whiteness 19-35. See also her monograph, Racism and the Image of God (New York: Palgrave Macmillan, 2010), where she declares, "Maintaining our own unfairly privileged status, we collude in our own failure to be fully human. To the Christian, this sad state of affairs should be unacceptable" (35).

57. Christopher Pramuk, Hope Sings, So Beautiful: Graced Encounters across the Color Line (Collegeville, MN: Liturgical, 2013) 3, emphasis original.

58. Laurie M. Cassidy, "Grotesque Un/Knowing of Suffering: A White Christian Response," in Christology and Whiteness 36-58. 
means not only a sustained practice of contemplative prayer, but even more so a contemplative stance toward reality, where "one sits in silence and reverence" so that God can make room in one's heart for the pain, suffering, and "luminous differences" of cultural and racial groups. ${ }^{59}$

O'Connell advances the arts as a form of what might be called tactile or somatic contemplation. Through such creativity, one can engage in the communal lamentation and profound intuition that move one out of the imprisoning impasses of social relationships and nourish a revolutionary social sacramental imaginary that births new visions and sustains deep hope. ${ }^{60}$ Notre Dame social ethicist Margaret Pfeil develops a form of mystical/political spirituality inspired by the Beatitudes to facilitate the struggle against white complicity. Rather than a set of discrete social or religious practices, this spirituality is "a way of being in the world that constitutes an act of resistance." Its core features include a commitment to nonviolent resistance; compassionate alertness to the perspective of the oppressed and suffering person; and a "keen contemplative awareness capable of rigorous systemic analysis."6l Finally, Catholic womanist theologian Diana Hayes provides a historical overview of African American spirituality in which she narrates "the worldview, traditions, stories, musicality, and religious beliefs" that have nourished and sustained this people in their ongoing struggle for full equality and quest for unqualified acknowledgment as human beings. ${ }^{62}$

What this concern for spirituality and contemplation reflects is the realization that racism poses challenges that cannot be redressed solely through political engagement or intellectual analysis. Deeper resources are needed that can undo the cultural malformation of white supremacy and provide the courageous hope needed for sustained social struggle.

\section{Retrieval of Protean Cultural Resources That Honor Black Agency}

Black Catholic historian Diane Batts Morrow reminds us that any adequate reflection on and analysis of racism must consider the agency of the oppressed, that is, how persons of color resisted, countered, and overcame the injustices to which they were subjected. ${ }^{63}$ The danger of a focus on whiteness and white privilege in recent Catholic reflection is that it recenters white people and neglects the perspective of the oppressed. That risk, though real, is lessened by the conscious, copious, and conspicuous attention given to the works of scholars of color by the authors examined in this survey. What distinguishes this literature is an uncommon commitment to be "intimately familiar with the work of scholars from underrepresented groups" ${ }^{\prime 4}$ or, in other words,

59. Pramuk, Hope Sings, So Beautiful 45-51, emphasis original.

60. O’Connell, If These Walls Could Talk 115-24, 187-93.

61. Mikulich, Cassidy, and Pfeil, Scandal of White Complicity chaps. 5 and 6.

62. Diana L. Hayes, Forged in the Fiery Furnace: African American Spirituality (Maryknoll, NY: Orbis, 2012).

63. Diane Batts Morrow, "Review Symposium," U.S. Catholic Historian 29.2 (Spring 2011) 61-63.

64. Teel, "What Jesus Wouldn't Do" 31. 
a willingness to be an apprentice of and responsible to scholarship that has been historically marginalized in both the church and the academy.

A few examples of this common feature will suffice. Jon Nilson's recent work seeks to establish a Catholic conversation with African American activist and writer James Baldwin. ${ }^{65}$ Bryan Massingale's current projects include advancing a Catholic reading of Malcolm X through showing his critical challenges to both the white theological guild and contemporary Black Catholicism. ${ }^{66}$ Karen Teel employs a sustained conversation with womanist scholars, both Catholic and Protestant, in her quest for an antiracist theological anthropology. ${ }^{67}$ Laurie Cassidy uses the perspectives of hip-hop culture to develop a searing critique of the white cultural logic that permits and requires the hyper-incarceration of men of color.$^{68}$ Christopher Pramuk employs the music of the black church as means of accessing the pathos of a culture different from his own. ${ }^{69}$ Finally, Maureen O'Connell, with brilliant lucidity, brings the voices of the urban poor into theological ethics through treating their creative expressions as living texts. ${ }^{70}$ What these scholars evidence, then, is what Catholic womanist theologian LaReineMarie Mosely calls a "sankofa ethics," that is, an ethical approach that entails a critical retrieval of lost or neglected sources in order to provide insight into full human flourishing, especially on the part of victims of sustained injustice. ${ }^{71}$

\section{The Importance of History}

James Keenan, in a previous contribution to these "Notes," provides a masterful overview of how ethicists use history in their professional projects. ${ }^{72}$ In recent Catholic scholarship on race and racial justice, one finds an abundance of historical works on African American Catholics that not only detail the struggles and triumphs of a beleaguered people but also retrieve useful lessons that need to inform current ethical scholarship. Gary Agee examines the career of Daniel Rudd, a black Catholic leader who was a major force in the influential Black Catholic Congress movement of the nineteenth century. ${ }^{73}$ Cecilia Moore mines the conversion experiences of

65. Jon Nilson, "Death, Racial Reconciliation, and the Mission of the Church-Baldwin's Perception," Journal of the Black Catholic Theological Symposium 5 (2011) 27-49; and "James Baldwin's Challenge to Catholic Theologians and the Church," Theological Studies 74 (2013) 884-902.

66. Massingale, "Vox Victimarum, Vox Dei"; and "Malcolm X and the Limits of "Authentically Black and Truly Catholic:' A Research Project on Black Radicalism and Black Catholic Faith," Journal of the Black Catholic Theological Symposium 5 (2011) 7-25.

67. Karen Teel, Racism and the Image of God (New York: Palgrave Macmillan, 2010).

68. Laurie Cassidy, "Hip Hop and the Seditious Reinvention of the Dangerous Black Man," in Mikulich, Cassidy, and Pfeil, Scandal of White Complicity chap. 4.

69. Pramuk, Hope Sings, So Beautifully.

70. O'Connell, If These Walls Could Talk.

71. LaReine-Marie Mosely, "Toward a Sankofa Ethics," Journal of the Black Catholic Theological Symposium 5 (2011) 51-88. Mosely relates that sankofa is an Akan word that means, "It is no taboo to go back and retrieve that which has been forgotten" (51).

72. James F. Keenan, "Moral Theology and History," Theological Studies 62 (2001) 86-104.

73. Gary B. Agee, A Cry for Justice: Daniel Rudd and His Life in Black Catholicism. Journalism, and Activism, 1854-1933 (Fayetteville: University of Arkansas, 2011). 
African American converts to Catholicism, relating their struggles to belong to a "white man's religion" and their efforts to combat racism within their church. ${ }^{74}$ Diane Batts Morrow's projects continue to illumine the witness of the Oblate Sisters of Providence, the first order of women religious established for women of African descent in the United States. ${ }^{75}$ Lincoln Rice's doctoral dissertation studied the twentieth-century life and activism of Arthur Falls, a Black Catholic Worker from Chicago, in order to sketch a vision of contemporary Catholic racial justice. ${ }^{76}$ Shannen Williams's dissertation at Rutgers studied the educational and political activism of African American Catholic women religious. ${ }^{77}$ Finally, Matthew John Cressler's dissertation will examine twentieth-century Chicago Catholicism and the decisive leadership roles these Catholics played in the Civil Rights and Black Power movements. $^{78}$

\section{An Incipient Shift from "Sin" to "Idolatry"}

A final characteristic feature of recent Catholic reflection on race, racism, and racial justice is the most nascent and perhaps the most radical. Both Massingale and Copeland argue that racial injustice and the white supremacy it expresses are not adequately understood by using the ethical categories of structural sin or intrinsic evil. Each now increasingly speaks of racism in terms of idolatry, a shift intended to capture the fullness of the crisis that Christian complicity in this social evil entails for authentic belief. Copeland's words are stark and uncompromising:

Racism spoils the spirit and insults the holy; it is idolatry. Racism coerces religion's transcendent orientation to surrender the absolute to what is finite, empirical, and arbitrary, and contradicts the very nature of religion. Racism displaces the Transcendent Other and selects and enthrones its own deity. ${ }^{79}$

Massingale is no less direct. Reflecting on recent papal liturgies where nonEuropean cultural expressions were publicly mocked, expressly denigrated, or specifically prohibited, he argues that

74. Cecilia A. Moore, "Conversion Narratives: The Dual Experiences and Voices of African American Catholic Converts," U.S. Catholic Historian 28.1 (Winter 2010) 27-40.

75. Diane Batts Morrow, “"To My Darlings, the Oblates, Every Blessing”: The Reverend John T. Gillard, S.S.J., and the Oblate Sisters of Providence," U.S. Catholic Historian 28.1 (Winter 2010) 1-26.

76. Lincoln Rice, "Toward a Renewed Theological Framework of Catholic Racial Justice: A Vision Inspired by the Life and Writings of Dr. Arthur Grand Pré Falls," PhD dissertation, Marquette University, 2013.

77. Shannen Dee Williams, "Subversive Habits: Black Nuns and the Struggle to Desegregate Catholic America after World War I," PhD dissertation, Rutgers University, 2013.

78. Matthew John Cressler, "Authentically Black and Truly Catholic: African American Catholics in Chicago from the Great Migrations to Black Power," PhD dissertation, Northwestern University, 2014. See also his "Black Catholic Conversion and the Burden of Black Religion," Journal of Africana Religions (forthcoming, Spring 2014).

79. Copeland, Enfleshing Freedom 109-10. 
U.S. and global Catholicism have been co-opted into an idolatrous belief system that practically maintains that the sacred and the holy can be definitively mediated and unambiguously encountered only through white cultural products. . . . The belief that God can be mediated or encountered unambiguously only through white or European cultural products is what I mean by ecclesial complicity in racial supremacy and is the essence of a compromised idolatrous identity. . . Can the church truly be the body of Christ in anything but the most rhetorical and nonincarnational way if it operationally believes that the Divine can be revealed, mediated, or encountered unambiguously [even normatively] only in white/ European cultural products? ${ }^{80}$

What is at stake, then, in racial injustice and exclusion are not merely ethical failures, that is, "sins," even if severe. Rather, the true "scandal of white complicity" is its bondage to a false god and its service to an idolatrous faith. The radical implications of understanding racism as a species of idolatry - whereby God can be truly imaged only in white-have yet to be fully realized. ${ }^{81}$ For example, what are the personal and ecclesial challenges of professing membership in an idolatrous faith community? How can a faith community be a carrier of authentic faith if it is complicit in whiteness, which, as a structure of racial dominance, is antithetical to the Divine? These are indeed scary questions. Yet this nascent reflection demonstrates why the subject of race-based idolatry can no longer remain of marginal interest in Catholic theological ethics. At stake is not mere moral credibility but the very integrity and authenticity of the faith itself.

\section{The Global Significance of Racilization}

Given the international audience of this journal, I attempted to discern how Catholic theological ethicists in other countries have responded to the summons to put racialization at the forefront of moral theology's agenda. The results have not been encouraging. ${ }^{82}$ No country has the amount or breadth of theological reflection that one finds in the United States. Let me briefly consider why this is of concern and then ponder some reasons for this silence.

A major reason why the relative silence of international ethicists is of concern lies in the simple fact that injustice in our world is still largely color-coded. Sociologist Howard Winant expresses this cogently:

80. Bryan N. Massingale, "Response: The Challenge of Idolatry and Ecclesial Identity," in Ecclesiology and Exclusion 130-35.

81. For a historical examination of the normative whiteness of Jesus in the United States and its social effects, see Edward J. Blum and Paul Harvey, The Color of Christ: The Son of God and the Saga of Race in America (Chapel Hill: University of North Carolina, 2012). In a forthcoming contribution, Massingale hopes to further his exploration of racial idolatry and its challenge to the church, using the Lonerganian understanding of "major authenticity."

82. I gratefully acknowledge the assistance of Andrea Vicini (Italy) and Alexandre Martins (Brazil) in providing resources and context for discussions of race occurring (or not) among Catholic moral theologians in their countries. 
Globalization is a re-racialization of the world. What have come to be called "North-South" issues are also deeply racial issues. The disparities in status and "life chances" between the world's rich and poor regions, between the (largely white and wealthy) global North and the (largely dark-skinned and poor) global South have always possessed a racial character. They are the legacy of a half millennium of imperialism. ... [Thus] globalization is a racialized social structure. ${ }^{33}$

In what remains the best examination of transnational Catholic ethical reflection on racism, Dawn Nothwehr calls colonization "an archetype of racism." ${ }^{84}$ Given that racebased slavery, conquest, and colonization are common foundational experiences that link the Americas, Europe, Africa, and Asia, their legacy and continuing effects are essential topics for moral theology's future deliberations, if it is to have an adequate understanding of and formulate effective responses to contemporary forms of injustice.

How, then, to account for the apparent silence of the global Catholic ethical guild on this subject? I see several factors at work. For one, in some countries there is an official policy of nonracialism (e.g., color-blindness) that inhibits the recognition of color-based disparities and their impact on social discrimination. ${ }^{85}$ In other countries the color-line is less evident; instead there exists a "color continuum" with a spectrum of skin variations. Despite the fact that the darkest peoples are disproportionately poor and marginal in social life, this continuum dilutes both the social consciousness of race and awareness of its impact in society. ${ }^{86}$ In still other countries, discussions of race are officially eclipsed by concerns over "citizenship," "national heritage," and "cultural identity." Thus their public debates center around the justice of immigration policies, the treatment of migrants, and the threats of a growing cultural heterogeneity to national identities. Left largely unnoted, however, are the marked racial overtones and subtexts present in such discussions of national identity and cultural heritage. Cultural heterogeneity is very often accompanied by racial pluralism. Thus the preservation of "cultural identity and heritage" can preserve and reinforce white cultural and economic dominance. ${ }^{87}$ Finally, in other countries color-based racism is not the chief

83. Howard Winant, The New Politics of Race: Globalism, Difference, Justice (Minneapolis: University of Minnesota, 2004) 131, emphasis original.

84. Dawn M. Nothwehr, That They May Be One: Catholic Social Teaching on Racism, Tribalism, and Xenophobia (Maryknoll, NY: Orbis, 2008) 30.

85. Winant offers South Africa as a case study of the effects of official nonracialism ( New Politics of Race 100-102).

86. For Winant, Brazil is a case study of the effects of a color continuum (New Politics of Race 102-4). I am grateful to Alexandre Martins for his frank discussions of the challenges of reflecting on race in the Brazilian context.

87. Winant offers the countries of the European Union as a case study (New Politics of Race 104-5). For a brilliant recent ethical analysis of the immigration debates that occur in the United States, see Kristin E. Heyer, Kinship across Borders: A Christian Ethic of Immigration (Washington: Georgetown University, 2012). As an aside, I recall the strong reaction that $M$. T. Davila received from some of Trento's participants when she offered the controversy over the prohibition of the public wearing of the burka by Muslim women in France as an instance of racialization. The objection was that this was a matter of French cultural integrity, not race. 
internal determinant of social stratification; rather tribalism and xenophobia are the more influential factors in their social conflicts. ${ }^{88}$

In short, color-coded racism is far from an insignificant factor in global affairs. Yet, it has unique manifestations and distinctive formative histories throughout the world. ${ }^{89}$ The summons to Catholic theological ethicists is to engage with the specific history and culture of their context and probe the effects of globalized racial formation in light of their particular legacy and its continuing impact.

Silence over race, racism, and racialization is not a viable option. These injustices are real and their reach is global. As African ethicist Agbonkhianmeghe Orobator explains, after recounting a particularly vitriolic racist encounter he experienced in a European country,

it is safe to assert that racism is alive not only in America but ... elsewhere in the world as well. ... The continent to which the policemen commanded me and my colleague to return is the object of historical prejudices, media stereotypes, and facile generalizations. [Thus] the tendency to equate black with inferior and white with superior is not a national obsession for the United States alone. ${ }^{90}$

\section{Remaining Work}

This survey began with the question, Has the silence been broken? The answer is both heartening and discouraging. Without doubt, we have seen significant progress in Catholic theological ethics regarding race. An impressive body of literature on racial ethics has appeared in the past five years that promises to have a far-reaching impact on how the discipline understands conscience formation in light of unconscious racial motivation; solidarity in the midst of social conflict; the impact of racialization on human sexuality; moral responsibility in light of a deeper appreciation of complicity in social evil; the role of the affections and emotions in the moral life; the cultural dimensions of human sinfulness; the importance of hope in social ethical reflection; and the connection between contemplative practice and transformative social action.

Moreover, future Catholic scholarship on race must continue and further its interdisciplinary character, drawing on resources from various branches of theology, the social sciences, and history. Furthermore, due to the historic exclusion of African Americans from the Catholic Church, reflection on racial justice in the United States must also engage with black Protestant scholars as well. Thus, recent scholarship on race, if it advances in these areas, promises to take the discipline of Catholic moral theology in new directions that are both exciting and pathbreaking.

88. Nothwehr, That They May Be One 4-8.

89. Nothwehr observed that in trying to expound a universal message about racism, Catholic magisterial documents treat of nine types of racisms, such as ethnocentricity, anti-Semitism, tribalism, and xenophobia (That They May Be One 75-81).

90. Orobator, "Struggle against Racism" 125-26. 
This scholarship, however, is still the work of decidedly few. Sadly, "racism does not yet appear as a theological or ethical priority for the church" or for the vast majority of its Catholic moral theologians. ${ }^{91}$ This, then, is perhaps the chief task that lies ahead, namely, both personal conversion on the part of Catholic theological ethicists and a corporate metanoia in Catholic moral theology. The serious need for such intellectual and affective conversion is by now apparent. In view of the increasingly diverse racial demography of the Catholic Church, both nationally and globally, and the fact that every major social justice challenge is entangled with and/or exacerbated by the reality of racial subordination, ${ }^{92}$ a moral theology that is blind to the reality of racism or deaf to its victims is not only inadequate to human experience, it also risks being an accomplice in social evil. The challenge given at Trento still retains its force:

We cannot, then, give an adequate account of present controversies and moral responsibilitiesmuch less develop a Catholic theological ethics for a world church-if we fail to attend to the voices of the dark bodies that hover over and haunt our histories despite our embarrassed silence and studied neglect. ${ }^{93}$

\section{Author biography}

Bryan N. Massingale received his STD in moral theology from the Academia Alphonsianum (Rome) and is currently professor of theological ethics at Marquette University. Specializing in social ethics, liberation theologies, African American religious ethics, and racial justice, he has recently published Racial Justice and the Catholic Church (2010); "Malcolm X and the Limits of 'Authentically Black and Truly Catholic': A Research Project on Black Radicalism and Black Catholic Faith," Journal of the Black Catholic Theological Symposium 5 (2011); and "A Parallel That Limps: The Rhetoric of Slavery in the Pro-Life Discourse of U.S. Bishops," in Voting and Holiness: Catholic Perspectives on Political Participation, ed. Nicholas P. Cafardi (2012). In progress are two monographs: one develops the contribution and challenge of Malcom X to Catholic theology; the other explores the intersections of race and sexuality and Catholic complicity in racialized sexuality/sexual racism.

91. Ibid. 126. One sorely felt need is for more ethical reflection on race and racial justice from the Latino/a perspective. See Davila's work referenced in $n .4$ above. Because of the continuing significance of antiblackness in US and global life, the black/white binary will continue to be critical and pivotal in future ethical discourse. The growing demographic complexity of US society, however, means that racial analysis from the Hispanic context must become more developed for the sake of effective Catholic ethical reflection and praxis. The work of Michelle Gonzalez is a helpful contribution. See her "The Jennifer Effect: Race, Religion, and the Body," in She Who Imagines 87-101.

92. Massingale, Racial Justice and the Catholic Church $\mathbf{x}$.

93. I wish to acknowledge Orbis Books, Palgrave Macmillan Press, and Liturgical Press for their conspicuous commitment to supporting and publishing the works of Catholic scholars engaged in the study of racism and racial justice. 